\title{
Imperial Desire and its Implications for Contemporary Representation of Colony
}

Etienne Rassendren*

\begin{abstract}
There has been much rigorous questioning about the idea and practice of colonialism in current reflections on colonialism and post/coloniality. Except for some serious intellectual examination over the inter-relations between gender and colonisation in Spivak's work on subalternity and gender, not much has been articulated about imperial desire and colonial sexualities. Moreover there has been no signifying exploration of the distinction between imperialism and colonialism particularly as the difference is situated in desire. This paper attempts to locate the difference between imperial and colonial as they overlap in imperial desire. I also wish to expose its continuity in contemporary representations of colony, particularly in film and conclude by making comments on pedagogic practices in the current English studies classroom. In so doing, I intend to situate the politics, both cultural and sexual, within the current representational politics of post/coloniality.
\end{abstract}

Keywords: Imperial, Colonial, Desire, Post/coloniality, Film, Pedagogic

* Associate Professor, Department of English, St Joseph's College, Bengaluru, India; erassendren@gmail.com 


\section{Introduction:}

Over some two decades now, much post/colonial ${ }^{1}$ studies has investigated a wide variety of issues and questions that surround the politics and practice of colonialism. These questions have related to political conquest, cultural violence and economic exploitation that both imperialism as ideology and colonisation as practice have been involved in. While much rigorous questioning of the continued practices of colony has been undertaken by critical theorists and literary polemicists, there is at least one domain of tremendous social and cultural ambiguity, namely that of 'imperial desire' that has yet to be fully probed and theorised adequately and systematically. Although there is much stimulating analysis in Spivak's work regarding questions of sexuality and gender in relation to subalternity and Third world women, there is an absence of, if sometimes only a muted, engagement with, the varied nature and practice of differing forms of imperial obsessions, of differing desires, coupled with intrigue and repression. These distort, if anything, the political and cultural milieu of pre/colonial and post/colonial conditions of 'desire' as well.

This 'desire', I argue, has indeed morphed contemporary cultural representations of colony, particularly in popular film texts, into imagery, a spectacle, so to speak, of colonial benevolence, reemphasising the civilisation rhetoric, which effectively constitutes current cultural politics. What is being missed is the nature of subtle subservience either foreign or indigenous which both colonial ideology and local tyranny have heaped upon the marginalised peoples of colonial and post/colonial society (Davies, 2016). This argument implies that an analysis of representations of colonial benevolence on the one hand and the exploration of colonial desire will most certainly expose the cultural-political nexus between local tyranny and foreign conquest. I intend

${ }^{1}$ I am using here formulation, which Davies (2016) has employed which suggests the inter-relatedness between the origins of colonialism and its continuities currently. The stroke instead of the hyphenation or its absence signifies the above (Davies, 2016). 
therefore first and foremost to explore the distinctions between imperialism and colonialism but above all to expose their overlap in what I understand as 'imperial desire'. I wish also to read Jonathan Gil Harris' The First White Firangis: Remarkable Stories of Heroes, Healers, Charlatans, Courtesans and other Foreigners who Became Indian (2015) concerning charlatans, healers, courtesans and other foreigners as a symptomatic, even over-arching, narrative of three specific forms of imperial desire namely a) the acquisition of tropical knowledge, especially of the landscape, its geography and its language; b) the 'become-Indian' notion of sexual dissidence (Harris, 2015, p.4) aimed at experimenting with or absorbing alternative sexualities in an exotic land; and c) the clever system of minimal extortion, minor theft and mercenary employment as the means to final authority and hegemony. I wish also to expose the continuities of imperial desire in current cultural representations especially in the following films: A Passage to India (1984); Gandhi (1982) and the more recent Lagaan (2001). In conclusion, I wish to comment on the pedagogic questions that a conflated approach to colonialism and anti-colonialism raises, particularly in the English studies classroom today.

\section{Conceptual Clarifications: The Difference and Overlap between Imperialism and Colonialism}

As suggested above, I wish at the outset, to make a few clarifications concerning certain conceptual frames that relate to inter-connections between imperialism, desire and benevolence; simultaneously, I wish also to situate these inter-relations within specific questions of post/coloniality that differs from other notions of postcolonialisms.

Often the terms, imperialism and colonialism have been used interchangeably to suggest that they are one and the same process; that unfortunately may be far off from its actual meanings and connotations. Imperialism, to begin with, is different from colonialism in relation to world history. In other words, imperialism anticipates colonialism by many centuries and goes right back into periods of antiquity, often to China and Egypt in 
ancient Asia and Africa and to Greece and Rome in antiquarian Europe. Therefore in terms of time-lines, colonialism is a much newer practice than imperialism is.

Secondly imperialism is an ideology that extends political and economic power of states and regions over others, often by direct conquest and at other times by subtle and more hegemonic means ("Imperialism", 2016). It often means that a foreign nation or kingdom, ruled by a monarch or an oligarch-pretending sometimes to be a democracy - sets out to control, exploit and rule over neighbours and/or far away spaces for surplus capital/profit, for territory and for political power. These are also aimed at maintaining fear over one's own subjects and those of the conquered in an attempt to attain status, assert power and subjugate people, so that rebellion or resistance of any kind may be suppressed and the tyranny of the conqueror and conquest may continue. Often thinkers consider imperialism as the idea that sets out colonialism as its practice ("Imperialism", 2016). Naïve as the distinction may sound, it does bear some truth-certainly not the whole truth - with regard to imperialism and colonialism

As for colonialism, it implies the domination of a group or state or kingdom over others, often far-flung and distant, accompanied by foreign settlement in other lands; it includes the acquisition of land and the subjugation of people. The forced or voluntary migrations of populations as in the Americas, South Africa, Australia and the Caribbean often accompany colonial activity. This factor complicates the colonial project, as it emphasises the importance of settlerdom over the politics of actual subjugation of indigenous peoples or citizens of actual nation states. Then one expects to call the British Raj an imperial system, whereas that of South Africa, a colonial one ("Imperialism", 2016). That may be highly problematic indeed. Settlerdom may or may not accompany colonialism, for it did not in India. Overseas trade established colony in India. Hence travellers rather than settlers enabled colonial activity.

Colonialism also includes rule by proxy overseas. Usually colonial activity rarely picks a local, conniving or consenting ruler; in fact it actually transplants a foreign governor or imperial lord overseas. Thus one has actually a foreigner to rule and execute a foreign 
system of governance and authority. The British Raj in India best illustrates this mode of colonialism. Hence it appears at least that with the British there is a symbiosis between imperial and colonial rule. Yet it is also true that the British also exemplified that specific $19^{\text {th }}$ century system, named colonialism. It is this conceptual ambiguation that I wish to unpack in what follows.

These above distinctions between imperialism and colonialism, while appropriate to a great extent gloss particularly two ideological processes, namely a) imperialism's ideological continuity and b) colonialism's hegemonic intrusions and extensions. Indeed, the idea of tyranny, forming the underbelly of imperial onslaught and the questions of civilising modernity underlying colonialism, both of which are undeniably present even today, are not addressed, despite the assumed overturning of imperialism and the so-called decolonisation of peoples all over the world. Thus, while acknowledging both as ideologies of domination and therefore of power (Horvath, 1972), the distinction could be more rigorously articulated when you see Imperialism as both an ideology and practice; and therefore as a clash between differing "hierarchies of power", that shaped the "trajectories" of the "regimes of power" of both the conqueror and the conquered (McClintock, 1995). But Colonisation too is about the establishment of foreign power in lands and among people for the business of rule, marked often by hegemonies of language and culture and worked through proxy rulers from the conquering kingdom, state or nation overseas ${ }^{2}$. Hence it seems that imperialism is an ideological attitude, a way of seeing the world around and marking it down, in appropriative co-optative and assimilatory ways. This way of seeing places and peoples then re-invents the politics of power and subjugation and paves the way for colonialism. Colonialism then re-invents the ideological frames of imperialism and is often a much more direct form of domination and subjugation, although these practices are not independent of hegemonies of cultural imperialisms. Colonialism also produces

2 This is drawn from a wide variety of sources including from McClintock (1995) and Young (1995). 
proxy states with foreign governors, while imperialism rarely does so.

Imperialism tends to produce vassal kingdoms, rarely proxy states. By that, I mean that imperialism implants a local warlord or satrap to do its bidding; often the Roman Empire had its own local rulers in the Mediterranean without sometimes having governors stationed there. In other words, one negotiated a true comprador so that the regime of control will succeed. Often rebellions would be quelled by the local satraps; at other times they will be fuelled by the disobedience of the local rulers themselves. Consequently the ideology of mastery and enslavement would be imposed by consent from the satrap; no rebellion will be tolerated, until and unless it bears the consent of the hegemon. Often such an ideology situates a peculiar regime of power, including that which extends beyond conquest. Hence imperialism tends to carry forth beyond its time in colony, as a subtle process of continued imbrication. Though its generic ideology remains undisturbed, it employs differing protocols, often hegemonies of benevolence, and coerce subtly without the knowledge of the subjugated, those very regimes, that breed consent. That apart, it changes its specific values and principles, not its generic intent, to re-establish smaller, sometimes more effective means of exploitation. Hence imperialism and colonialism are different processes, though the one might influence the other.

Imperialism is integral to colonialism, while colonialism need not always constitute imperialism. This difference is best illustrated in the three differing ways through which the imperial unfolds in British practice. The first of these is through a form of imperial discourse that exoticises, if sometimes, eroticises the other, i.e. it distorts what is visible with what is expected by a European audience. Indeed those portraits and landscapes of the differing other, while attempting to remain only symbolic, are often invested with the gross imaginaries of European fantasies. It is here that libidinal Europe encounters its unnameable alterity, much like the way, Conrad perceives the so-called western man in the primordial heart of Africa (Conrad, 2016). For Asia and India, in particular, these were representable in the courtesan, the homosexual, the hookah and the insatiability of sexual gratification above all. 
The second lies with the entire discourse of anarchy imposed on the conquered, an oriental one often, which includes the notion of the despot, the lack of law and order and the problems of legitimacy. Indeed this means that one lacked a juridical system, absent of a sense of modernjustice, while relying on custom and tradition, to resolve disputes. Thus these presumed oriental spaces were unmodern, waiting to see enlightenment, from their imperial master. This is why, sati becomes more an act of terrifying social depravity, while witch-hunting and burning at stake are historical inevitabilities - while one knows that both these actions are attacks against women and constitute sexual violence everywhere. The exoticism rests often in portraying, i.e. representing to the audiences back home, the skewed cruelty of local, social and sexual hierarchies. This argument does not condone sati at all, just because it is Indian and indigenous. In fact that would be a serious misconstruing. Sati is certainly a most cruel masculinist act. It requires both condemnation and abolition; it also implies the lack of sexual justice. But the colonialists have not been sexually just either; for their numerous witch-hunts and bride-burnings, they still have remained backward. But the power of their discourse set out a primitivisation of the 'native' social polity in order to achieve hegemonic dominance. In other words, the deployment of sati in colonial discourses is a deliberate imperial deployment and is liable for discursive critique as well (see Mani 1989, Sangari \& Vaid, 1989).

The tropics also unravel a whole series of rare tropical experiences, particularly in its natural biology, the bodies of men and women, the fruits and plants, the climatic conditions and the food and taste that need to be named and brought to knowledge. Therein lies another unmapped language, a phraseology, which neither the European sciences nor its arts could substantiate. Therefore civilising the uncivilised as the imperial agenda suggests depends on the appropriation of tropical knowledge, because it implies renarrativising the tropics in terms of both its polity and its biology.

The third aspect that remains more obvious than others is the ambition to wealth. Asia for its spices and its great many lavish 
princely states, its precious metals, and its natural resources, was perceived as an economic destination. That the overseas was a career for particularly mercenaries, Da Gama and Robert Clive included, does not precisely bear out all this romance with the East. Indeed the numerous other travellers, including the Venetian Manucci, who besides plotting a traveller's history, and also remaining in the payroll of the Mughal prince who loses his battle of succession to the more strident Aurangzeb, actually claim knowledge of these others, through a process of acquisition. In other words, this desire to bring to knowledge what otherwise was absent to modern learning makes possible capital accumulation through both the differing stories (erotic love stories) and exoticist knowledge (herbal and tropical medicine) of what is tentatively assumed to be India ${ }^{3}$.

These three aspects of imperialism and their trajectories sometimes in the colonial process, I argue, constitute imperial desire. They can be succinctly marked out as a) the exoticisation and distortion of male/female bodies, particularly in sexual violence and political anarchy; b) the sexualising of both people and places in covert exercise to establish one's own dissident sexuality; and c) the economy of surveillance over the Indian landscape to map and bring to knowledge the tropical world of rich and lavish natural and trade resources for capitalist exploitation.

In view of the above analysis of imperial desire, I wish here to read three narratives, from Harris' The First White Firangis: Remarkable Stories of Heroes, Healers, Charlatans, Courtesans and other Foreigners who Became Indian (2015) not always fiction, and not always history, but somewhere in-between; it belongs to the kind of liminality and hybridity (Young 1995, p. 165) that would expose the shaping of both imperial desire and anti-imperial resistance. It is this doubleness that I wish to track as a tropology of imperial thought and representation in contemporary cultural-politics

\footnotetext{
${ }^{3}$ I have used many sources for the preceding mapping of imperialism and desires, chief among them being McClintock (1995), Young (1995) and Harris (2015).
} 


\section{The First White Firangis: Harris' Celebrations and Pitfalls}

Three stories that Harris' narrates to substantiate the encounter of imperial desire with imperial power remain iconic in the way in which colonialism and later its contemporary benevolence are encapsulated.

The first remains the tale of Garcia da Orta, the Portuguese physician whose interest in Arabic and Indic medicine between the years 1534 and 1569, from when he landed with is Amo, his lord and master, and the Portuguese "fidalgo-warrior" is to turn him into an imperial trope, a trickster of the European imperium and the ultimate hero of the history of imperial desire. Orta's master and fidalgo becomes the viceroy of Estado da India, with his viceregal seat at Goa. Orta from the payroll of his European master makes his many successful transformations from the Portuguese doctor through his experiments with tropical medicine, both Arabic-Persian and Hindu-Indian, to his final exploits in the botanical explorations in Ahmadnagar in Gujarat. Orta travels far and wide and faces many tragic moments, including the death of his sister to the Inquisition. He has to get used to Indian spices in his regular day-to-day meals. He struggles with severe stomach disorder but he adjusts absorbing its tastes and its many prevarications. He experiments with the Aam, the mango, growing gardens both in the North and South of Goa and sending to and trading with Portugal those fruits and extolling their virtues in some of his letters. Besides, he learns local medicine from his GoanKonkani friends, until he takes to being the physician to the Sultan of Ahmadnagar, where he learns from the Persian-Arabic Hakeem, the differing cures for fevers and other stomach ailments. He returns to Goa where he dies and is buried in the cemetery there. He leaves behind a major treatise on Eastern medicine, botany, and other miscellaneous knowledge, titled Colloquies, about the world he lived in, far away from his native Portugal. What the stray accounts of this doctor's travels and experiments do not tell however, but research has shown, are the following: that the good doctor is suspected to have converted to Islam nominally because of his love for Oriental knowledge in Ahmadnagar; he has played 
the good Catholic in Goa and supported everything Portuguese; yet again his own antecedents, leaving from the University of Salamanca, may seem obviously Catholic, but they may have been Jewish refugees from the Portuguese border with Spain. Garcia Orta's original Hebrew name could well have been Avraham and throughout his writings Orta's Jewishness is clearly visible. This however seems like the first one for us: the true hybrid, the ultimate Creole-Jewish-Portuguese-Catholic-Muslim-GoanHakeem-botanist-doctor-mango lover (Harris, 2016, p. 22-46). Effectively, the eternal trickster indeed, who absorbs lavish oriental tastes, assimilates then by Eurocentric textualisation and redeploys them as exotic knowledge acquired in the Orient. There is certain kind of jouissance, "the pleasure of the text" of the Orient (Howard, 1975), an ecstatic expressivity and reading, emerging out of the presumed mastery over alien languages, exotic tastes and consequently, the reified everyday. This indeed is desire, the ecstasy of knowing, and the reading pleasure of the Eurocentric imagination.

This story provides us with the specific imaginary of the knowledge-seeker, that form of desire that emphasises mapping the local landscape in order totextualise the other. This habit is ultimately aimed at "worlding" 4 the text of the Indic, the other Orient' - an extension of the Persian-Arabic and the Indic-tropical system of anarchic naturalism and absolutist tyranny. In other words, Orta is one such writer and thinker, traveller and imperialist that would mark orientalist perspectives as the universal episteme of master-knowledges of the Occident. Hence this constitutes imperial desire of the kind that speaks of bringing everything to knowledge so that it becomes accessible to all in Europe and elsewhere. It also provides us with the kind of imperial roguery that establishes knowledge as a universal system. It emphasisesa mercenary attitude that invokes assimilation; imagine, from Jewish origins, through militant Catholicism, to Islamic

${ }^{4}$ This term is common and implies bringing what is unaccounted for to knowledge. It was the habit of imperialists to scientificise in order to acquire ways of handling both the assumed anarchy and enhancing control over the unmapped lands and their peoples (Spivak, 1999). 
Persian informant- that, indeed, is the archetypal tale of the benevolent yet rogue-imperialist. It also eroticises the new and uncertain tropics, with all its natural splendour as both the split-self and the cursed other (see Lacan, 2001) 5 .

The second story is that of a Portuguese woman, namely Juliana Dias da Costa, (Harris, 2015, p. 150-184) who eventually carries the title, the Jagiridar of Jogabai, the latter name signifying now a vast area of land in Delhi that includes the Jamia Millia Islamia University. This really is the story of a 'court-girl', born of a renegade Portuguese catholic, after the sack of Hooghly, in Mughal times. She seems like a zenna child, the product of a Harem, a slave's daughter, who rises up to dizzy heights as a landowner and public personage, in the years of Shah Alam, soon to become Bahadur Shah. Her early years seems to be punctuated by many drifts, from sometime being only a slave-girl through being highly respected for her medical skills to finally achieving glory as a Jagiridar. Yet she seems to have been merely a court-girl of purchase, forced to cross-dress to appear in the Mughal court, be rejected by men such as Manucci, but riding alongside the Mughal king and visiting her lands, with a larger retinue. She seems to have children out of marriage, often servicing the queer tendencies of some the court's men, as there is record of her grand-children. But her biggest act of assertion is her role as mendicant for the rulers and the woman of the harem.

Juliana Dias da Costa is an ambiguous figure of both legend and history; she appears to carry the doubleness of a woman capable of rising to the top of the rank, while she simultaneously seems to service Mughal or renegade firangi men, with their queer tendencies and desires. She was obviously martial in appearance sporting a sword on her hilts and wore headgear as befits a Mughal woman; yet one sees the nature by which this absorption into local community both alienates as it includes. For Juliana, the court was a space of opportunity as it was also an entrapment of desire.

5 I am playing off Jacques Lacan's perspective of the 'other' being displaced as the split-self. See Lacan, Jacques (2001). 
Juliana represents the complex crises of European sexualities, which somehow find fair acceptance in the so-called depraved Oriental East.

The symbolism that such a story carries is certainly in the realm of sexual dissidence. Juliana is both male and female at once, a sexual ambiguity that authors and legitimises queerness, one which European morbid morality abhors but also desires simultaneously. Hence Juliana services both heterosexual and homosexual desire in a way that frees European sexual discontents but also enervates the notion of Oriental sexual ambiguities. As Robert Young states the fear of sexual deviance, is often marked by a sense of race and racism (Young, 1995, p.168). Between the repulsive but the primordial attractiveness of blackness, to the voluptuousness of Southern Asia, the European fantasy to explore sexualities and to frame alterities became central to the very foundations of imperial possibilities. That far away from home, there could remain some boundary-crossing (McClintock, 1995, p. 101), some sexual transgression that remains both hateful and ecstatic at the same time features as singular trope of inter-mixing of races and the ambiguities of sexualities. Therefore it remains valid that sexual adventure like cross-racial, cross-sexual activity remains common in imperial Asia and more specifically of India.

The third and final story is that of Nicolai Manucci (Harris, 2015, p. 255-279), who comes on the payroll of an English lord and realises in no time, that his master has died and he is the object of interest of two ragtag English thieves, the two dakiats of Hoodal, both also working as mercenaries in Shah Jahan's forces, but intent on stealing Manucci's holdings from his master.Manuccui strays into Shah Jahan's court, studies Indian medical habits, maps them and soon moves further south to Madras and St Thomas Mount to become a wealthy house-owning individual; he is certainly the first firangi siddhavaithier, that the South had known. Here is profession as property; his desire for herbal explorations enables his skills as a local mercenary historian of science and his abilities of healing grant him wealth enough to have the respect of others around. He marries and does settle down as all imperialists and colonialists did as part of their economy of settlerdom. 
Thus as earlier discussed there is a spectrum of discursive symbolisms that enables the inter-linkages between sexuality and gender, power and wealth and knowledge and authority. These have often been morphed into specific metaphors that configure a tropology of imperial desire. In our analysis further, I wish to argue that these metaphors constitute current representations of both imperialism and colony.

Harris' book sounds in its fine lingual gymnastics and in its people's history mode, an apology to colonial violence. It appears to suggest that hybridity was so real that one could not differentiate between European Catholic-Christians and IndicIslamic warlords. It also suggests that the sexual exploration and the ambiguities of sexual preference were possible in the depraved, not necessarily the free Orient. Hence the eroticisation of the Indic continues to exemplify deviance, not openness. The disguises, the switching of identities and the role-playing, continue to re-entrench the notion of the Indic-orient as the sexual other. However what Harris' text shows is the intricate nature of liminal, hybrid spaces of history and its implication for desire, acquisition, and roguery. That, therefore, offers a tropology that signifies the imperialcolonial design and practice.

It seems obvious then, that much imperial desire, particularly of the kind that you see in Harris' historicity, is largely about the sexualpolitics of Europe itself. The case of Juliana epitomises the grave discomfort with Europe's sexual mores and gender relations. The freedom to be the Jagiridar, a ruler, almost male, owning land, and dispensing authority, was probably impossible in Europe itself. That apart, to be attractive to men and women alike, to being ambiguously male in outlook and behaviour and uncertainly female in one's ways and style sets out the complex blurring between Jagiridhar and Jogabhai, between sexualities known for its intersexedness as also its queerness. Thus the Indic-Orient is both free and uncertain, open and deviant at the same time. The cases of both Orta and Manuccui constitute knowledge as desire - the mapping, the recording, the herbal experimentation, all encompass the desire for the other in knowledge. 
The analysis so far leads us to the following discussion about how these forms of imperial desire inflect contemporary representations of colonial benevolence and imperial desire.

\section{Three Films and Current Representations of Imperial Desire}

Much of this analysis above informs us about Imperial desire through a symbolic representation of insatiable over-sexualisation of the other. That men, and sometimes women, search after oriental and otherwise differentiated others may have been quite recurrent. Literary representations play this romance of the libidinal orient out regularly. One sees these in relative regularity in the association of such desire with animals-often baboons and monkeys are associated with the libidinal (Young, 1995, p. 150). The emphasis of the baboon attack on Adela in David Lean's A Passage to India (1984) - an adaptation of E M Forster's goodbye to India, namely, $A$ Passage to India (1924) and a Thorn EMI and HBO production-is symbolic of this attribute imposed on the Oriental. Although this discursive attribute is associated with black women in many imperial narratives and discourses, the reverse seems plausible too, particularly because of the fear that some colonialist thought proposes: the power of sexual deviance, of white women being infatuated by dark men (Young, 1995, p. 145-146). In other words, the white male moralist presumes in his utterly patriarchal insinuation that the ultimate white female fantasy in the colonial context is rape by dark-skinned men. It is precisely this underlying patriarchal theme that the scenes in the Marabar Caves in David Lean's A Passage to India (1984) carry forward, one which the novel keeps thoroughly ambiguous and uncertain. It is the narrative of the film, a more recent feature and symbolic representation, which plays out the sexual violence, implicated in imperial sexual politics. The notion of the Indian doctor as respectable but sexually deviant is played out without hesitation in the film. But what the film never fully acknowledges is that such impressions, even actual behaviours, are part and parcel of Eurocentric sexual politics. In the process, the film racialises the Indian making him out to be an emasculated cartoon, given to extremes of affection and disaffection. The baboon attack in relation to the symbolic order of 
representation in the film anticipates what is later perceived as errant sexual violence in the Marabar caves. Indeed it is this gender insensitivity that does not propose an adequate sexual resolution for Adela and it appears like a punishment for the sympathies with what some call mongrelisation (Young, 1995, p. 101). This habit of seeing India as the otheris further represented in the completely static nature that characterises other Indians; the scenes in which the elite Indian women stand guard as both Fielding and Adela pass by is ridiculously immobile.

What is visible is the symbolic structuration of oriental sexuality, that which is often substantiated by its deviance. But it is precisely this deviance of imperial infatuation, the desire to be absorbed into an anonymity of sexual dalliance, which is impossible within the metropolitan centre. Hence between Harris' account of Jogabhai and the representation of Adela in David Lean's film, there is an overlap of imperial sexualities that represent European desire in its far-flung boundaries in empire and colony.

In Richard Attenborough's Gandhi (1982), there are a few moments that focus the notion of knowledge acquisition as 'desire' along the lines of the assimilated and indigenised Gracia da Orta, scientist, Hakeem, agriculturalist, and Manuccui, the military advisor and siddha vaithier.

To begin with, consider the scene of the sedition trial of 1922 in Ahmedabad, a few months after the infamous Chauri Chaura incident. The judge presiding is R S Broomfield, who as Gandhi enters, rises in respect, and shocks the whole court, with his action. Gandhi argues that he accepts the Advocate General's indictment for which the Judge simply remarks:

It is impossible for me to ignore that you are in a different category from any person I have ever tried or I am likely to try. Nevertheless it is my duty to sentence you to six years imprisonment. If however his majesty's government should at some later date, see fit to reduce the term, no one would be better pleased than I (Attenborough, 1982) 
It seems as if at this precious moment, the British remember their essential liberalism and their commitment to law. Yet this scene's symbolism expresses the British's profound understanding and benevolence of its Indian freedom fighter and subject, the nonviolent Gandhi. Somehow it feels as if the British moral fibre has been deeply devastated by both the incongruence of its law and the non-violent challenge a weak and simple man posed to its relevance. It further suggests that somehow the British by that time know that alternative thinking and practice against the rigidities of imperial authority are at play. This knowledge breeds respect of the kind that Orta has earlier of the local life and native intelligence. This indeed is the vicarious pleasure of herbal medicine, the sights and smells that much audio-visual representation of the Orient produces. I would invoke the commonplace of this in cinematic representations such as Alexander (2004/2005) particularly in the way in which India and her spices, kings and sexualities are represented.

There is a great deal of symbolic valorisation of what might be called Vedantic spirituality and knowledge. General Smuts of South Africa earlier is represented as kind and gentle soul, deeply affected by the reverberations of an alternative spirituality, the nature of non-violence and civil disobedience. This is often pitchforked against the rather violent policemen who beat Gandhi up while he burns his passes - that incident, untrue historically. Further still, General Dyer is tried particularly because he does not understand the varied nature of ahimsa; Kallenbach's visit to Jinnah's Gardens repeats symbolically what the Portuguese Manucci and Orta did in Goa, Gujarat and Tamil Nadu; the arrival of an English Admiral's daughter, Mira, systematically configures an exotic India keenly saturated with tropical forms of knowledge and an equally alternative form of spirituality. In fact the film produces an iconic order that resorts to orientalist discourses about the tradition-bound Indic peoples, with their numerous myths, customs, and rituals. It also suggests that the British in their benevolence for the other have learnt the wisdom that encompasses all of the so-called Indic society. The judge's behaviour, Mira's constant attendance of Gandhi during his fasts, Kallenbach becoming one with Sabarmati-all merely re-tell the desire for the other in knowledge and sexuality. 
In Lagaan (2001) an Amir Khan starrer, the economy of Company taxation, which exploits the subjugated Indians, is seen and ordered as a game, through, of course, cricket, the paradigmatic of fair-play which valorises British liberalism. The game itself is represented as a European duel, the desire for which is mediated by the flirtatious betting, the cruel meandering and the helplessness of the local Prince. It seems as if the indomitable spirit of the colonised and the empowerment gained from the desire of the memsahib, Elizabeth Russell, Captain Russell's sister, which finally destroys the imperial plot. This invokes the imagery of the benevolent and the sexually active memsahib, whose love for the protagonist, Bhuvan, on the one hand and her so-sad for-them sense of redemption on the other propels the narrative into a story of benevolence and justice. She learns the local language, much like Orta does, extolls the virtues of simple village life, almost valorises the idyllic nature of the orient and mourns its loss at the behest of modernist intrusions, especially at the end of the film. This reminds us of Orta's valorisation of the Aam, a trope that signifies much the same exhortation of pleasure or its displaced reverse, namely sacrifice. Systematically, the narrative uses the symbolic body of the woman, her deep attraction for the young Indian man, to establish the pitfalls of colony, once again, making the coercive tale into a refraction of English justice and colonial desire. This indeed is an alternative sexual-politics that combines the ambitions to wealth and acquisition and sexual absorption and assimilation.

Indeed then the three films illustrate differing forms of imperial desire ranging from the politics of sexuality in the body through the dalliances of discovering tropical geography and botany to the expectation of imperial control through law and order. Besides one hears of subtle appropriation, a certain sympathy and a somewhat intriguing acquiescence of alterity itself. Whether this image of the Indic-Oriental is true to the historical accounts of firangis is only relevant to the extent its symbolic order situates the imaginary of the orient itself. Yet it foregrounds the Eurocentric imaging of the orient, in a way that marks out the desire to own, deviate, explore, experiment and assimilate both in the body of colony and the 
worlding of knowledge. Thus Imperial desire is central to imperial and colonial power.

Consequently, it is obvious that what is perceived as imperial desire well before British colonialism seems to be recovered in contemporary representations of colony. Instead of a post-colonial inflection to resistance, the current representation re-installs much of the imperial desire that early European intrusions enforced. Thus while there are differences in the forms between Portuguese's interests and current desires, the continuities of imperial desires as the underbelly of co-option remains intact. Thus the post-colonial condition will have to question the imperial desire in terms of the Eurocentric vision of sexuality, the cultural economy of knowledge and the power of exploitative wealth underlying current postimperial cultural-politics.

\section{Conclusion:}

It seems as if all this deliberate distinguishing between imperialism and colonialism is but hair-splitting. But pedagogic questions, particularly in an English studies classroom teaching postcoloniality, is all about difference. Often in the teaching of postcolonial resistance, there is great conflation of ideas. Sometimes, the comprador is mistaken for the mixed, the hybrid, and the liminal; it somehow appears as if they are replaceable. Often then, historicity is blurred i.e. the nature of periodization and its attendant chronologies are not adequately distinguished especially if imperial means colonial as well. Yet, one fails to differentiate approaches and situate the politics appropriately. Consider if one is to treat the imperial Firangis, the same way one treats the colonial Robert Clive. What one would have is a misconstruing, a complete conflation, the uncritical emphasis of universalising all Europe and all white as an undifferentiated occident. That would repeat exactly what is contested. Hence it becomes essential to distinguish, discern and differentiate. The second is the effort to unduly reify so-called colonial benevolence as if somehow the charity or the cricketing kind of fair-play is sufficient while differing hegemonies and dominations continue under the colonial powers. Until and unless a truly signifying assessment is made of the proclivities of colony, this misplaced appreciation of British fair-play, seems ironical. 
While the so-called Raj exploits, the exploited thank the colonialists for that. More to the point, it is not an undifferentiated panning down that one expects; rather it is a more assiduous and responsible invocation of difference. Indeed, despite the violence and ugly dismembering by cultural imperialism, modernity arrives in and through colonialism's underbelly, whereas imperialism rarely seeks to bring anything more than itself.

That apart, every English studies classroom is multi-lingual, carrying languages that are, not just as vastly different as there are regions, i.e. as different as Hindi is to Tamil but also as different as social economies are from each other i.e. as different as Dalit languages are to upper-caste idioms. That indeed is the cultural difference that one requires to respect, which is also why one needs trueindisciplinarity, a striking clash of voices, which only multicultural pedagogy can offer. Indeed then, only that which combines the Social Sciences with the Humanities, politics, and desire, sexuality and colony can succeed in negotiating the variedcultural, political spaces that the multiple languages of the English studies classroom occupies. Of course then, all is political, namely the literatures and the arts, culture and sexuality, power and imperialism, colonialism and language.

\section{References}

Attenborough, R. (Producer and Director). (1982). Gandhi: the Film [Motion Picture]. United Kingdom/India: Goldcrest Films, International film investors, National Film Development Corporation, Indo-British Films.

Brabourne, J., Goodwin, R. B., (Producers) \& Lean, D. (Director). (1984). A Passage to India [Motion Picture]. United Kingdom/United States: Thorn EMI and HBO.

Conrad, J. (2016). Heart of darkness. Retrieved from https://www.free-ebooks.net/ebook/Heart-of-Darkness.

Accessed on 7Feb 2016 
Davies, D. Post/Colonial Writing - Introduction. Retrieved from https://writersinspire.org/content/postcolonial-writingintroduction on February 07, 2016.

Harris, J. G. (2015). The first white firangis: Remarkable stories of heroes, healers, charlatans, courtesans and other foreigners who became Indian. New Delhi, India: Aleph/ Rupa publications.

Horvath, R. (1972). A definition of colonialism. Current Anthropology, 13(1), 45-57.

Howard, R. (1975). A note on the text. In The pleasure of the text by Roland Barthes (R. Miller,Trans.) (pp. 5). New York: Hill and Wang.

Imperialism. (2016). In Encyclopædia Britannica. Retrieved from https://www.britannica.com/topic/imperialism

Khan, A., Khan, M., (Producers) \& Gowariker, A. (Director). (2001). Lagaan: Once upon a time in India [Motion Picture]. India: Amir Khan Productions.

Lacan, J. (2001). Ecrits: A selection. London, UK: Routledge classics.

Mani, L. (1989). Contentious Traditions: The Debate on Sati in Colonial India. In K. Sangari and S. Vaid (Eds.), Recasting Women: Essays in Indian Colonial Society. Delhi: Zubaan, Kali for Women.

McClintock, A. (1995). Imperial Leather: Race, gender, and sexuality in the colonial context. London, UK: Routledge.

Sangari, K., \& Vaid, S. (1989). Recasting women: Essays in Colonialhistory. New Delhi, India: Zubaan, Kali for Women.

Schully, T., Kilk, J., Iain, S., Borman, M., (Producers) Stone, O. (Director). (2004/2005). Alexander [Motion Picture]. US /France/ UK: Intermedia Films, Ixtlan Productions, France 3 Cinéma, Pacific Film, Egmond Film \& Television, IMF Internationale Medien und Film $\mathrm{GmbH}$ and Co. 3 Produktions KG.

Spivak, G. (1999). A critique of postcolonial reason: Toward a history of the vanishing present. Cambridge,USA: Harvard UP Print.

Young, R. (1995). Colonial Desire: Hybridity in theory, culture and race. London, UK: Routledge. 